\title{
Development of an aspheric 22-diopter 50-mm diameter magnifier
}

\author{
Desenvolvimento de uma lupa asférica de 22 dioptrias de $50 \mathrm{~mm}$ de diâmetro
}

\author{
José Américo Bonatti ${ }^{1}$ \\ Fernanda Alves da Silva Bonatti ${ }^{2}$ \\ Maria Cecília Loschiavo dos Santos ${ }^{3}$ \\ Pedro Carlos Carricondo ${ }^{4}$ \\ Newton Kara-José ${ }^{5}$
}

\begin{tabular}{l} 
ABSTRACT \\
\hline Purpose: To develop in an interdisciplinary approach between ophthal- \\
mology and design areas an ergonomic +22-diopter 50-mm aspheric hand \\
magnifier for low vision. Methods: An aluminum cylinder was cut, \\
processed using a lathe and carved to produce a ring that accommodated \\
a 50-mm aspheric lens, with an external depression not to slide from the \\
holder's fingers. A cylindrical steel bar was cut, processed using a lathe \\
and carved in order to form an externally turned ring to be screwed into \\
the internal thread of the aluminum ring, to maintain the lens in a steady \\
position. Both rings were submitted to electrostatic painting with a dull \\
black electrostatic Epoxi ink, except the lower border of the external ring, \\
to indicate the correct side of the magnifier to face the material to be read. \\
Results: A 22-diopter 50-mm diameter aspheric lens magnifier with ablack \\
ring to be hold at its external circular depression was obtained in order to \\
safely search the adequate reading focus with an inferior aluminum colored \\
ring to face the object to be read and allow a less distorted reading. This \\
is the first Brazilian high-magnification great-diameter magnifier for low \\
vision that permits basically the focusing on an entire word, not only \\
syllables, in order to allow a faster and more comfortable reading. Conclu- \\
sions: By an interdisciplinary approach a 22-diopter 50-mm aspheric lens \\
magnifier was developed with image and ergonomic characteristics such \\
as to permit comfortable and adequate reading performance in cases of low \\
vision.
\end{tabular}

Keywords: Vision, low/rehabilitation; Lenses; Visual acuity; Equipment design

\section{INTRODUCTION}

Low vision is a serious and increasing public health problem, mainly in the over 60 -year-old population, where $80 \%$ of the cases occur, affecting $6 \%$ of people over 65 and $20 \%$ of people over 85 -years-old in Europe and in the United States ${ }^{(1)}$. As the proportion of seniors in the population increases (a phenomenon observed both in developed and in developing countries like Brazil) low vision leads to a dramatic increase in direct and indirect costs of eye care. The number of those older than 60 in Brazil is projected to be $10 \%$ of the total population by $2010^{(2)}$.

Low vision (LV) is defined as any chronic visual condition not correctable by glasses that impairs everyday function and causes blindness by a loss of useful vision. It may be caused by several diseases, like age-related macular degeneration, diabetic retinopathy, macular chorioretinitis, glaucoma in adults and chorioretinitis, retinopathy of prematurity and congenital glaucoma in children. As treatment for macular diseases leading to low vision the use of positive special spectacle lenses with higher addi- 
tions, prismatic high addition spectacle lenses, hand magnifiers and electronic magnifiers can be cited for near vision. Most of low-vision patients remain in the first three treatment categories.

The first historical registers on the existence of rudimentary lenses were written in China by Confucius, around $500 \mathrm{BC}$. By the time of Aristotle (384-322 BC) man produced cut rocks in a way to make possible their use as an optic instrument. It was only in the Middle Age that monks began to develop the "reading rocks", according to the more perfected theories of the Arab mathematician Alhazen, who lived in Basra (around the year 1000). This rock functioned as a primitive magnifying glass that increased the size of letters, being basically composed of hyalin quartz crystal or semiprecious rocks submitted to stonecutting and polishment ${ }^{(3)}$. In 1270 Marco Polo found aged Chinese using eyeglasses for reading. There are indications of the appeareance in Venice (Murano), by the end of the $\mathrm{XIII}^{\text {th }}$ century, of a spectacle with a pair of lenses to be placed in front of the eyes, with the purpose of reading. However, the first aid for optical correction was attributed to René Descartes in 1637, who described a glass cone with a plain frontal surface and a concave posterior surface ${ }^{(4)}$.

One can easily find prismatic and non-prismatic spectacle high addition positive lenses in Brazil being produced by the local optical shops. However, when one needs higher magnification (over +12 diopter lenses), the spectacles are not the solution. The use of over +16 diopter aspheric hand magnifiers, with larger lens diameter for reading comfort achievable by the asphericity is generally necessary. This kind of lens is a not easily found and is an expensive imported product. The easy-to-find magnifiers in the market are positive spheric low-diopter great-diameter or high-diopter small-diameter, both not satisfying adequately moderate to severe low-vision patients, due to the low magnification in the first case and to incomplete reading of a magnified word in the second case (one can only see syllables of a long word at a time because of the small diameter used to avoid spherical aberration).

It could to be said that the practical limit for the use of hand magnifiers is around 28 diopters, because they tend to have a small diameter limiting their use, mainly if the lenses are not aspheric. Above 28 diopters the use of electronic magnifiers, which certainly are much more expensive and less practical then the hand magnifiers is usually indicated.

Today, more than ever in Brazilian history, the Brazilian government research agencies like FAPESP and CNPQ and universities like the University of São Paulo (USP) are stimulating the cooperation between the university and scientific entrepreneurs, through scientific enterprises incubators like CIETEC located inside USP as an strategy for the development of innovative knowledge, following the model adopted in developed countries, contributing to the transformation of our country in a generator of innovative products, overcoming its current position of commodities exporter. This results in better employment opportunities for highly educated people and in more taxes for the government than raw mate- rial production. In 2006, in an interdisciplinary association between university people and a scientific enterprise incubated at CIETEC, the CNPQ-Brazil Design for Health Group was created, with people from the University of São Paulo Ophthalmic Clinic, the University of São Paulo Architecture and Urbanism School and Bonavision Auxilios Opticos Ltda.

Based on the low vision people's demand for an aspheric ergonomic high magnification great diameter hand magnifier this CNPQ-Design for Health Group worked on the development of the first Brazilian +22 dipoter aspheric hand magnifier described below.

\section{PURPOSE}

The purpose of this paper is to show the development of an ergonomic +22-diopter 50-mm aspheric hand magnifier.

\section{METHODS}

The following materials supplied by Bonavision were used: $57 \mathrm{~mm}$ diameter cylindric aluminum bar, $57 \mathrm{~mm}$ diameter cylindric steel bar Epoxi electrostatic dull black ink, +22diopter 50-mm diameter aspheric lens.

The aluminum cylinder was cut and processed using a lathe until it had the shape of a ring with an external circular depression in order not to slide from its holder's fingers. Internally, in order to accommodate the $50-\mathrm{mm}$ aspheric lens, this ring was processed using a lathe forming an inferior plate to hold the inferior border of the lens and superiorly it was carved forming a thread. It was called external ring.

The cylindrical steel bar was cut, processed using a lathe and carved in order to form an externally turned ring to be screwed into the internal thread of the aluminum ring, with the purpose of maintaining the lens in a steady position. The steel ring, called internal ring, was submitted to a galvanization process to avoid rusting.

Both the external aluminum ring and the internal galvanized steel ring were submitted to electrostatic painting with a dull black electrostatic Epoxi ink, except the lower border of the external ring, which is to be the correct side of the magnifier to face the material to be read.

Thereafter the circular depression of the external ring was YAG-laser engraved with the name of the enterprise Bonavision and $22 \mathrm{D}$, respectively the name and the lens power.

Finally, the lens was mounted on the plate in the internal part of the external ring and the internal ring was screwed to the external ring onto the lens to maintain its steadiness.

\section{RESULTS}

A 22-diopter 50-mm diameter aspheric lens magnifier with a black ring to be hold by its external circular depression (Figure 1) in order to safely look for the adequate reading 
focus (Figure 2) and with an inferior aluminum colored ring to face the reading object in order to permit less distorted reading was obtained.

\section{DISCUSSION}

Thinking about developing products for whatever populations, the aim is the best quality as possible. In this case the challenge was to develop a great-diameter high-power ergonomic magnifier. The solution was found using an intermediate high-power (22-diopters) aspheric lens, that permits good reading of an entire word in its $50-\mathrm{mm}$ diameter with few peripheral optical aberrations and image distortions, allowing a better interpretation and reading of a given word, because the users usually have defects regarding continuous reading of a word, having to interpret or imagine

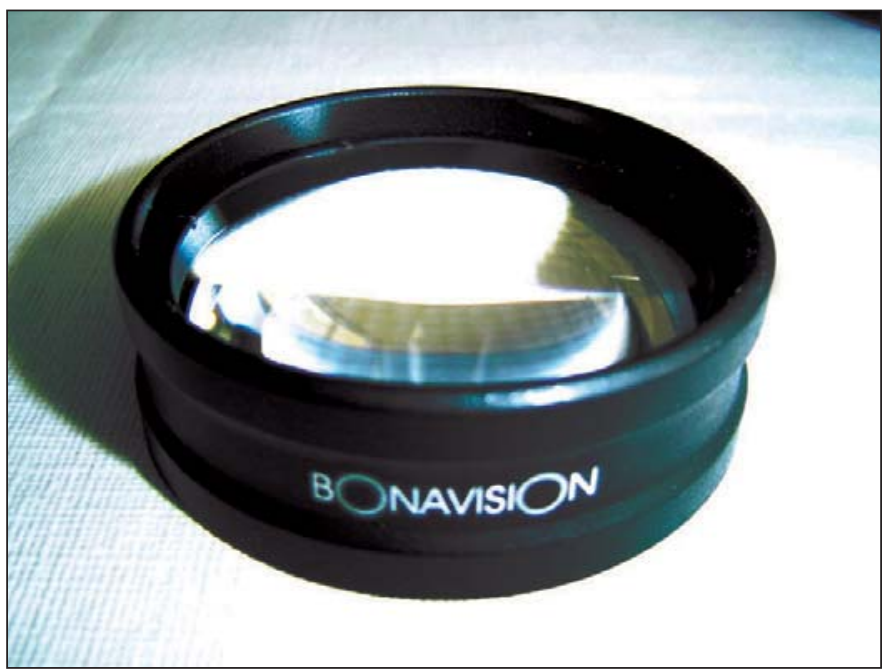

Figure 1 - Magnifier with its external circular depression

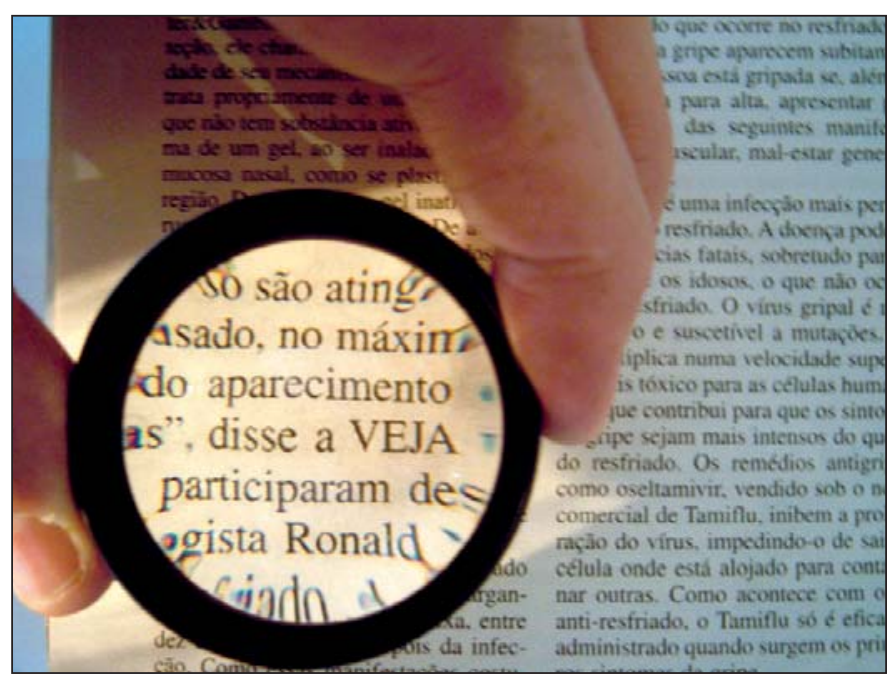

Figure 2 - Magnifier showing entire words and more than one text line these defects. This process is certainly the faster the better their education, but when aided by less aberrated lenses like the aspheric ones their task is easier. Differently, the common high-power spheric lenses, because of their small diameter, when used with the same magnification as the aspheric, only permit the reading of one or few syllables of a word, making reading a boring and slow process.

This intermediate high-power (22-diopters) was also used because it would permit writing under the lens on the paper beside reading, because the space between the lens and the paper is adequate (focal distance about $4.5 \mathrm{~cm}$ ). With higher power lenses writing is almost impossible.

Besides the technical aspects of the lens itself leading to good reading, we were also concerned about the ergonomic and design aspects of this developed magnifier, in order to permit comfortable utilization. With this goal a light material, the aluminum, for the external ring (the bigger one), a dull black resistant Epoxi painting of the rings in order to avoid reflections and an external circular depression of the external ring to avoid escaping of the magnifier from the holder's fingers were provided. The non-painted inferior border of the external ring can easily signalize to the patient the right side of the magnifier to face the paper to be read in an easy way like "the white (almost, of the aluminum) facing the white (the paper)".

All this development was done with design features as to permit the product to be efficient and user-friendly in terms of aspect and touch, aiming a better compliance with the low vision treatment.

Besides its use for low vision, the developed magnifier could also be used by ophthalmologists as indirect ophthalmoscopy lens, because of its adequate $50-\mathrm{mm}$ useful diameter and $+22 \mathrm{D}$ aspheric lens power.

This magnifier can be evaluated in other studies by low vision patients.

The development of this magnifier allied the knowledge of designers and medical people. It must be emphasized that this kind of initiative can and must continue to be practiced in this so devoid sector of our country, because visually impaired people often need this multidisciplinary approach to have optimized solutions for their problems and also not to be stigmatized.

The most observed picture in Brazil is the development of ophthalmic equipments on an isolated basis ${ }^{(5-10)}$, not using design to make the usability of a given product easier. A strategy of development of bioengineered products, with socially responsible design ${ }^{(11)}$ in the ophthalmic area focused on low vision people certainly brings them benefits. The social responsibility is also a response to the necessities of the population ${ }^{(12-15)}$. This work needs the participation of ophthalmologists and designers, besides the collaboration of a specialized staff as engineers, physicists and others, to help in the solution of the interface problems these projects present. Accessibility and inclusion have also to be considered. An example of successful interaction at the University between 
Ophthalmology and design was the development of an equipment to aid low vision people on near reading, with the purpose of both satisfying the optical necessities and adapting the machine to the man (ergonomics), resulting in an equipment ${ }^{(16)}$ with functional and asthetic characteristics to make the reading of common texts (as periodicals, books, notebooks and magazines) more comfortable, without losing reading line.

The interdisciplinary work associated with a scientific enterprise shown in this paper resulted initially in the design of an ophthalmic equipment for low vision, opening the possibility of a vast fan of researches, contributing to increase the number of scientific publications and the innovative technological development in our country.

\section{CONCLUSIONS}

A 22-diopter 50-mm aspheric lens magnifier was developed with image and ergonomic characteristics such as to permit comfortable and adequate reading performance.

\section{RESUMO}

Objetivo: Desenvolver de modo interdisciplinar entre as áreas de oftalmologia e design uma lupa de mão ergonômica de +22 dioptrias de $50 \mathrm{~mm}$ de diâmetro asférica para baixa visão. Métodos: Um cilindro de alumínio foi cortado, torneado e teve feita internamente uma rosca a fim de produzir um anel para acomodar uma lente asférica de $50 \mathrm{~mm}$ de diâmetro com uma depressão externa para não escorregar dos dedos do portador. Uma barra de aço cilíndrica foi cortada, torneada e teve uma rosca feita para formar um anel com fio de rosca externo para ser rosqueado na parte interna do anel de alumínio, para manter a lente em posição estável. Ambos anéis foram submetidos a pintura eletrostática preta fosca exceto a borda inferior do anel externo para sinalizar o lado correto da lupa a ficar voltado para o material a ser lido. Resultados: Foi obtida uma lupa de 22 dioptrias de $50 \mathrm{~mm}$ de diâmetro com um anel preto para ser segurado pela sua depressão circular externa a fim de procurar com segurança o foco adequado de leitura e com um anel inferior aluminizado para apontar para o objeto de leitura e permitir uma leitura menos distorcida. Esta é a primeira lupa brasileira de grande diâmetro e grande aumento para baixa visão, asférica, permitindo a focalização de uma palavra inteira, não apenas sílabas, proporcionando leitura mais rápida e confortável. Conclusão: Foi desenvolvida de modo interdisciplinar uma lupa de +22 dioptrias, de $50 \mathrm{~mm}$ de diâmetro, asférica, com tal qualidade de imagem e características ergonômicas para permitir leitura de desempenho adequado e confortável em casos de baixa visão.

Descritores: Baixa visão/reabilitação; Lentes; Acuidade visual; Desenho de equipamento

\section{REFERENCES}

1. Plut A. Alívio para os olhos. Revista 20/20 Brasil. 2000;(16):40-2.

2. Especial: Estatuto do idoso. Jornal do CREMESP. 2004;2(198):8.

3. Camargo ML. A História dos óculos. Sinopse Oftalmol. 2000;1(3):71-5.

4. Goodrich GL, Arditi A. An interactive history - The low vision timeline. In: Stuen C, Arditi A, Horowitz A, Lang MA, Rosenthal B, Seidman K, editors. Vision rehabilitation: assessment, intervention, and outcomes. Lisse: Swets \& Zeitlinger; 2000. p.3-9.

5. Suzuki H, Suzuki R, Suzuki CR. Diatermo coagulador bi-polar coaxial: modo de construção. Arq Bras Oftalmol. 1995;58(3):175-6.

6. Suzuki H, Suzuki R, Suzuki CR. Gancho de íris para dilatação mecânica da pupila: modo de construção. Arq Bras Oftalmol. 1995;58(5):367-8.

7. Cavalcante I. Ataque à miopia com raio laser. J USP. 1991;5(171):12.

8. Oliveira AC, Yasuoka FMM, Tonissi-Jr SA, Cansian AM, Ramos JEB, Romão AC, Bonatti JA, Castro-Neto JC. In: $15^{\circ}$ Encontro Nacional de Física da Matéria Condensada. Caxambu; 1992. São Paulo: Sociedade Brasileira de Física; 1992. p.157.

9. Bonatti JA, Suzuki H, José NK, Matheus LCA. Desenvolvimento de equipamento de geração e registro de pressão intra-ocular suportada por perfuração corneana colada com fibrina. Arq Bras Oftalmol. 1997;60(5):514-5.

10. Haddad MAO, Sampaio MW, Kara-José N. Auxílios para a baixa visão. São Paulo: Laramara; 2001.

11. Cooper R. Ethics and altruism: what constitutes socially responsible design? Design Manage Rev. 2005;16(3):1-17.

12. Garcia BG. Responsabilidade social das empresas: a contribuição das universidades. São Paulo: Editora Fundação Petrópolis; c2002-2003.

13. Papanek VJ. Diseñar para el mundo real: ecología humana y cambio social. Madrid: H. Blume Ediciones; 1977.

14. Papanek V. Arquitetura e design: ecologia e ética. Lisboa: Edições 70; 1995.

15. Whiteley N. Design for society. London: Reaktion Books; 1993.

16. Bonatti FAS. Desenvolvimento de equipamento de auxílio à visão subnormal. Arq Bras Oftalmol. 2006;69(2):221-6. 